\title{
Studi Kelayakan Core Iron Stator dengan Metode Loop / ELCID Test
}

\author{
Riza Samsinar ${ }^{1}$, Nurritwan Purnomo ${ }^{2}$, Deni Almanda ${ }^{3}$ \\ Jurusan TeknikElektro Universitas Muhammadiyah Jakarta \\ J1. Cempaka Putih Tengah 27 No. 47, Jakarta10510 \\ E-mail: riza.samsinasr@ftumj.ac.id,nurritwan@gmail.com,deni.almanda@ftumj.ac.id
}

\begin{abstract}
Core iron adalah Inti besi stator yang terbuat dari bahan ferromagnetic atau besi lunak disusun berlapis-lapis untuk tempat terbentuknya fluks magnet. Agar pembangkit listrik dioperasikan secara efisien, ketersediaan komponen harus memiliki kualitas yang tinggi dan dicapai oleh generator. Untuk memastikan hal ini, kondisi generator harus diperiksa secara teratur dan direncanakan secara prediktif. Inti besi stator generator yang berumur selalu berada di bawah beban selama beroperasi dan diakibatkan oleh tekanan mekanik, termal, dan listrik. Secara khusus, isolasi antara ribuan laminasi individu dapat rusak selama operasi berlangsung dan pada saat generator bekerja. Isolasi yang rusak bisa menghasilkan arus eddy yang lebih tinggi dan hot spot lokal, yang berangsur-angsur menyebar. Oleh karena itu, sangat penting untuk memastikan bahwa isolasi antar laminar tetap utuh, untuk mencegah kerusakan akibat konsekuensi seperti pembakaran inti atau kerusakan pada isolasi batang. Kerusakan pada isolasi batang dapat menyebabkan gangguan antar elemen stator dan kegagalan mesin secara tuntas, EL CID adalah tes Fluks Ring (fluks penuh) yang membutuhkan pasokan listrik besar, tenaga kerja yang cukup, dan kamera pengamat inframerah yang mahal.Hasil dari penelitian ini mengahatui bagaimana kondisi core iron stator pada tiga generator dengan daya yang sama dan tahun pemasangan yang berbeda masih layak digunkan atau tidak dengan menggunakan alat Elcid test yang terdiri dari ELCID ,Manual trolley, Chattock, kabel eksitasi ,regulator tegangan manual switch box / terminal, dan Laptop
\end{abstract}

Kata kunci : Core iron , Arus, Manual trolley , ELCID Test ,Chattock, Terminal , laptop

\section{PENDAHULUAN}

Core iron adalah Inti stator terbuat dari bahan ferromagnetic atau besi lunak disusun berlapis-lapis tempat terbentuknya fluks magnet. Motor dan generator merupakan komponen kunci pada generasi daya dan aplikasi lainnya [1]. Operasi pembangkit tenaga listrik harus aman dan terpercaya. Agar pembangkit listrik dioperasikan secara efisien, ketersediaan komponen kuncinya yang tinggi, generator, harus dicapai. Untuk memastikan hal ini, kondisi generator harus diperiksa secara teratur dan direncanakan secara prediktif. Inti besi stator generator yang berumur selalu berada di bawah beban selama operasi dan diakibatkan oleh tekanan mekanik, termal, dan listrik. Secara khusus, isolasi antara ribuan laminasi individu dapat rusak selama operasi berlangsung dan saat pekerjaan dilakukan pada generator. Isolasi yang rusak bisa menghasilkan arus eddy yang lebih tinggi dan hot spot lokal, yang berangsur-angsur menyebar. Oleh karena itu, sangat penting untuk memastikan bahwa isolasi antar laminar tetap utuh, untuk mencegah kerusakan akibat konsekuensi seperti pembakaran inti atau kerusakan pada isolasi batang. Kerusakan pada isolasi batang dapat menyebabkan gangguan antar elemen stator dan kegagalan mesin secara tuntas.Uji Deteksi Ketidaksempurnaan Inti Elektromagnetik (EL CID) diterima di seluruh dunia untuk mendeteksi insulasi insulasi inti antar-laminar yang aman dan aman.Satusatunya alternatif untuk tes Evolusi Iris Power EL CID adalah tes Fluks Ring (fluks penuh) yang membutuhkan pasokan listrik besar, tenaga kerja yang cukup, dan kamera pengamat inframerah yang mahal.Peningkatan "Arus Eddy" membuat titik-titik panas yang pada dasarnya dapat menyebabkan kerusakan lebih lanjut dan tidak dapat diprediksi pada isolasi laminasi inti atau inti sebenarnya (peleburan inti). Tidak terdeteksi dan tidak terkendali,halini dapat menyebabkan kerusakan insulasi peredam stator, sehingga mesin tidak berfungsi lagi. ELCID adalah alat perawatan efektif biaya untuk memverifikasi integritas laminasi inti stator. Deteksi kegagalan insulasi interlaminar pada inti stator generator besar juga telah didiskusikan [2]. Hasil dari penelitian ini mengetahui bagaimana kondisi core iron stator tiga generator dengan daya yang sama dan tahun pemasangan yang berbeda masih layak digunakan atau tidak dengan menggunakan alat Elcid test yang terdiri dari ELCID , manual trolley, chattock, kabel eksitasi, regulator tegangan, dan manual switch box / terminal , dan laptop. Pengukuran diagnostic untuk evaluasi generator pada rugi faktor dan uji induksi tinggi telah dipublikasikan [3]. Kondisi insulasi perlu di periksa untuk mencegah kebakaran [4]. Kerusakan besi stator bisa terjadi secara mekanikal atau electrical [5]. 
Wktu terbaik untuk menguji lilitan adalah setelah lilitan telah di pasang pada inti stator [6]. Keandalan generator besar adalah sangat penting untuk menjaga integritas ketersediaan daya [7]. Industri petrokimia menunjukkan tingkat kegagalan yang lebih sedikit untuk motor sinkrn dibandingkan industry lainnya [8]. Salah satu cara untuk menguji insulasi interlaminasi adalah tes ELCID [9]. Laboratorium pusat elektro di UK telah mengembangkan metode untuk mendeteksi kegagalan di inti interlaminasi insulasi dengan cara elektromagnetik [10], [11]. Kebutuhan akan pengujian yang lebih sederhana yang aman dan cepat ada sejak tahun 1970 dan ELCID merupakan cara uji yang memiliki fliks rendah dan non destruktif [12]. Elemen resistif dari komponen arus yang gagal dari sinyal chattock diindikasikan oleh QUAD mpd [13]. Arus yang lebih besar dibutuhkan untuk memagnetisasi inti karena arus berlawanan mengalir pada laminasi ketika frekuensi meningkat [14]. Kegagalan yang dalam bisa dideteksi dengan metode induksi tinggi karena panasnya terlalu terdifusi ke dalam inti yang menyebabkan kenaikan suhu yang sangat kecil pada permukaan [15] . Pada umumnya, inti inti dari mesin listrik dikenakan pada proses yang berbeda ang bisa mengakibatkan pengaruh langsung seperti kerusakan mekanis, partikel asing, getaran, panas dan kerusakan insulasi [16]. Penggunaan koil toroida pertama kali diperkenalkan oleh A.P. Chattock pada abad 19 [17]. Ada sejumlah permasalahan yang akan dipecahkan pada penelitian ini yaitu: Bagaimana cara menganalisis core iron stator tiga generator dengan daya yang sama dan tahun pemasangan yang berbeda untuk mengetahui kelayakan core iron dengan cara metode loop atau menggunakan ELCID Test sebagai alat untuk mendeteksi panas / hot spot pada core iron Adanya masalah yang akan di pecahkan yaitu:

1. Pengambilan data hasil pengukuran menggunakan alat ELCID Test

2. Core iron yang digunakan core iron stator generator .

3. Metode pengambilan data hasil pengukuran dipindahkan dalam bentuk output word

Tujuan penelitian ini untuk menganalisis kelayakan core iron stator pada generator dengan menggunakan ELCID Test untuk mendapatkan temperature / suhu hot spot pada core iron dalam bentuk data grafik yang sesuai dengan standard pada pengukuran

\section{METODE}

Core iron adalah inti besi stator yang terbentuk dari ribuan lembar baja tipis (laminasi) dan berliku terbentuk dan terisolasi elektrik bar konduktor tembaga yang tertanam di slot antara gigi sekitar inti. inti dipegang bersama oleh bangunan baja bar, yang terletak di luar inti Laminasi yang dilapisi dengan lapisan tipis isolasi listrik untuk mencegah arus eddy yang disebabkan antara mereka dengan memutar fluks magnetik yang dihasilkan oleh rotor berputar

Kerusakan atau cacat pada antar-laminar isolasi menyebabkan kesalahan arus yang mengalir secara lokal di inti. arus ini dapat menghasilkan pemanasan lokal yang berbahaya atau hot spot di kawasan yang rusak dan kerusakan inti dapat menjadi semakin buruk. Dalam kasus ini panas yang cukup ekstrim dapat menghasilkan atau mencairkan lapisan isolasi di bagian-bagian kecil dari inti dan bahkan naik dalam suhu inti yang berdekatan dengan belitan , dapat mengakibatkan kegagalan prematur isolasi belitan. Jelas hot spot harus dideteksi dan diperbaiki selama overhaul / perbaikan mesin secara rutin. metode tes yang ada dikenal sebagai cincin penuh pengujian fluks mengharuskan intinya untuk selalu mendekati tingkat fluks bekerja secara normal untuk jangka waktu tertentu. Kenaikan suhu yang mengakibatkan panas pada titik inti karena setiap panas pada titik inti kemudian diukur.

Oleh karena itu, dianjurkan untuk secara teratur memeriksa kondisi insulasi, untuk menghindari kerusakan konsekuensial seperti pembakaran inti atau kerusakan pada isolasi batang. Isolasi batangan yang kurang pasti dapat menyebabkan kesalahan stator ground yang dapat menyebabkan gangguan yang tidak terjadwal.Uji fluks digunakan untuk mengukur kondisi isolasi inti stator dan dengan demikian mendeteksi kemungkinan kerusakan insulasi lokal. Kegagalan isolasi dapat menyebabkan hot spot lokal antara beberapa inti inti selama magnetisasi. Bintikbintik panas ini dapat dideteksi dan dilokalisasi dengan thermal imaging.

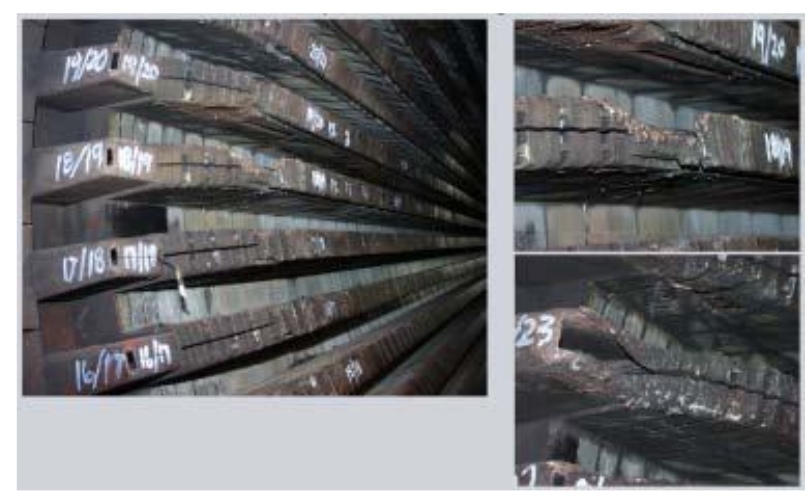

Gambar 1. Bentuk kerusakan core iron [18]. 

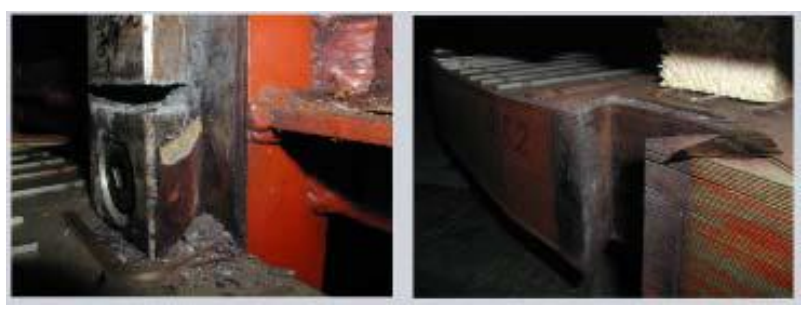

Gambar 2. Jejak terbakar inti stator karena fluks magnet yang berlebihan [18].

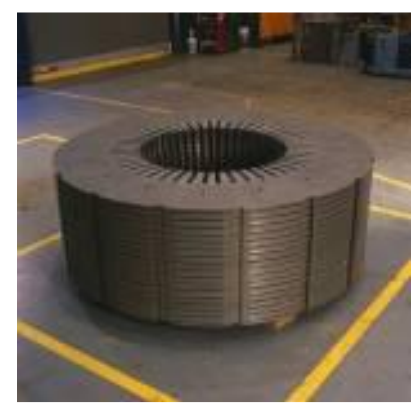

Gambar 3. Tumpukkan core iron [18].

Metode alternatif deteksi kesalahan dalam inti interlamination isolasi dengan cara elektromagnetik dikembangkan pada tahun 1978 oleh Pusat Pembangkit Listrik Board (CEGB) dari Inggris (sekarang RWE Innogy plc). Alih-alih tingkat kerja penuh fluks metode ini hanya menggunakan sebagian kecil dari nilai eksitasi untuk menghasilkan arus kesalahan dalam inti tubuh yang dirasakan oleh kumparan pick-up. Hal ini untuk menghindari masalah pengujian biasanya ditemukan dengan eksitasi tinggi, namun masih memberikan indikasi yang akurat dari kawasan yang rusak di sepanjang kiat gigi dan dinding Slot, serta kemungkinan kerusakan sub-permukaan. Sistem ini disebut EL ectromagnetic $\mathrm{C}$ bijih Saya mperfection D etector (EL CID). Hak untuk teknologi diakuisisi oleh ADWEL International Ltd pada tahun 1982, yang dilanjutkan pengembangan dan pembuatan produk. Pada tahun 2007 ADWEL digabung menjadi Iris Daya LP, dari siapa berbagai pilihan EL peralatan CID sekarang tersedia. Fleksibilitas dari EL CID juga memberikan manfaat lain seperti:

a. catatan pengujian permanen otomatis

b. cara melakukan tes lokal yang sederhana untuk pin menunjuk dan pemantauan perbaikan

c. kecepatan dalam pengaturan dan pengujian mesin besar atau kecil

d. kurang interpretasi subjektif dari hasil

e. berarti memperkirakan disipasi daya kemungkinan sirkuit kesalahan di bawah kondisi operasi

f. tidak ada peralatan mahal tambahan g. menghindari kerusakan tambahan yang disebabkan oleh cincin penuh pengujian fluks sedangkan inti tidak didinginkan

h. sensitivitas tinggi untuk mendeteksi bahkan kesalahan kecil dan ketidaksempurnaan inti

Teknologi EL CID pengujian inti stator mensyaratkan bahwa medan elektromagnetik yang dihasilkan dan dipancarkan, meskipun kehendak ini tentu sangat jauh lebih sedikit daripada dengan pengujian fluks cincin penuh konvensional. Frekuensi yang dihasilkan biasanya yang terkait dengan instalasi pembangkit listrik dan amplitudo sinyal akan cenderung lebih rendah daripada lingkungan umum. tingkat latar belakang ini biasanya lebih rendah di bengkel perbaikan, namun masih bisa dominan. Akuisisi sinyal kesalahan memerlukan deteksi tingkat yang sangat rendah medan elektromagnetik, dan ini dapat mencakup sinyal yang dihasilkan oleh peralatan lainnya dan instalasi (misalnya. Pengelasan, crane overhead dll). Sinyalsinyal palsu biasanya tidak hadir masalah dengan pengujian EL CID tapi mungkin dalam keadaan ekstrim menguntungkan untuk waktu akuisisi uji jejak dengan aktivitas dari sumber sinyal menghasilkan lainnya. Pengguna harus memastikan bahwa instalasi sistem uji kompatibel dengan peralatan lain yang digunakan selama uji ELCID

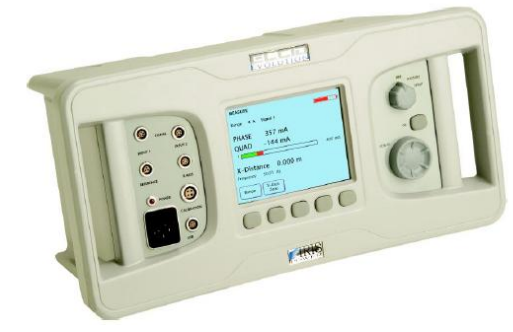

Gambar 4. ELCID Evolution system.

\section{Prinsip kerja Alat}

Elcid Tes merupakan alat yang digunakan untuk mengetahui atau Menganalisa Core Iron stator dalam kondisi baik atau tidak dengan cara Melilitkan Kabel / menggunakan toroidal berliku untuk menghasilkan fluks Cincin untuk mendeteksi magnetis arus dari efek pemanasan yang dihasilkan Daya yang dibutuhkan cukup rendah dalam kapasitas standar 120 V dan 240 VAC Untuk kapasitas mesin cukup besar lalu chattock diposisikan ditepi luar Dari dua slot yang berdekatan dan sinyal output akan berisi bagian karena kedua, bidang eksitasi dan setiap saat kesalahan diinduksi secara lokal. Unit EL CID Signal Processing mendeteksi sinyal Chattock, dan analisis itu Sehubungan dengan sinyal referensi yang diambil dari arus eksitasi. Bagian Dari sinyal dalam fase 
RESISTOR (elektRonika kEndali telekomunikaSI tenaga liSTrik kOmputeR) Vol. 1 No. 2 e-ISSN : 2621-9700, p-ISSN : 2654-2684

dengan referensi (sinyal TAHAP) didominasi karena Medan magnet yang dihasilkan dari eksitasi inti . Sinyal diproses dari Chattock untuk setiap pasangan yang berdekatan gigi dicatat untuk Memberikan serangkaian jejak QUAD untuk setiap slot. Ini menunjukkan Posisi sepanjang inti dan amplitudo dari setiap arus kesalahan dan sinyal Processing dikirim ke unit ELCID dalam bentuk grafik sinyal untuk mengetahui kondisi core iron hot spot atau tidak

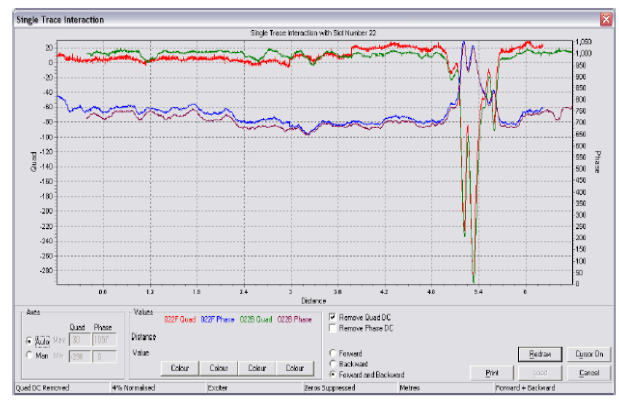

Gambar 5. Ilustrasi hasil pengukuran core iron.

- Spesifikasi Alat

a. Komputer/Laptop: untuk memonitoring hasil pengukuran

b. ELCID Test : untuk mendeteksi hot spot pada core iron

c. Manual trolley : untuk di tempelkan lalu didorong dinding core

d. Chattock kalibrasi : untuk memberikan sinyal ke ELCID

e. Sumber daya : untuk suplay daya sebesar $120 /$ 240 VAC

f. Tang Ampere : untuk mengetahui arus yang mengalir

- Diagram blok alat

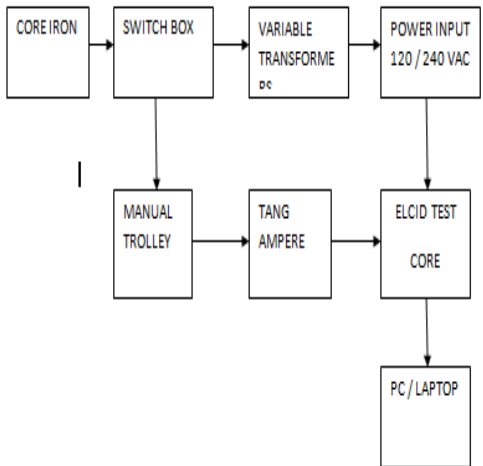

Gambar 6. Blok Diagram pengujian ELCID TEST.
- Wiring diagram pengujian ELCID

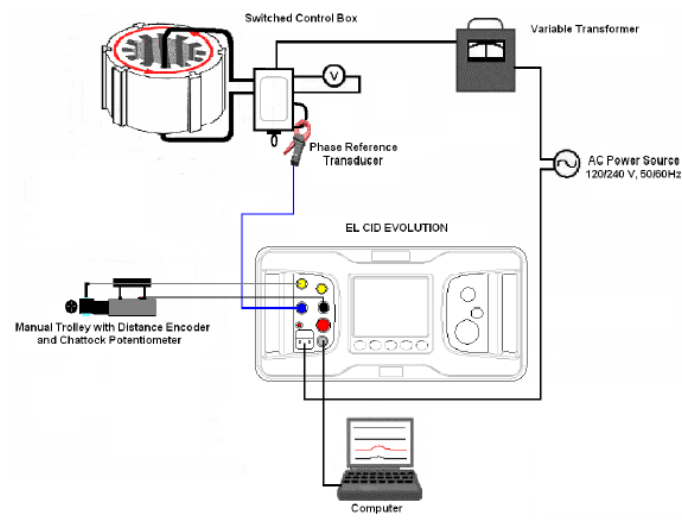

Gambar 7. Wiring diagram ELCID.

- Flowchart pengujian ELCID

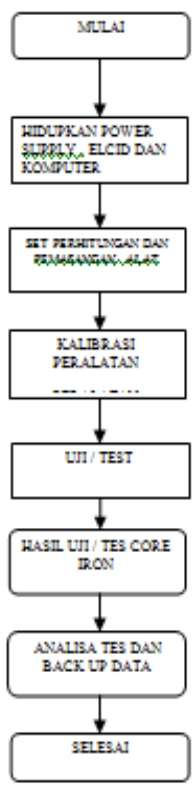

Gambar 8. Flowchart Pengujian ELCID.

- Persiapan pengujian ELCID Test

- Persiapan umum / Peralatan tambahan

1. Sebuah bangku untuk peralatan EL CID, kertas

2. pencahayaan lokal untuk menerangi interior area inti dan bekerja

3. Kayu derek kedua sisi inti atau beberapa cara lain untuk memberikan posisi yang optimal dan tensioning dari eksitasi berliku

4. tali non-logam (misalnya. polypropylene 6-8mm) untuk mendukung eksitasi berliku

5. Sebuah senter karet untuk pemeriksaan close-up dari lubang stator

6. Putih pita perekat dan spidol atau serupa untuk penomoran slot stator 
RESISTOR (elektRonika kEndali telekomunikaSI tenaga liSTrik kOmputeR) Vol. 1 No. 2 e-ISSN : 2621-9700, p-ISSN : 2654-2684

- Memeriksa alat pengujian ELCID

1. Periksa semua konektor EL CID, kabel, dll untuk tanda-tanda isolasi yang rusak terkena kabel atau konektor logam. Hal ini penting karena hingga $50 \mathrm{~V}$ dapat diinduksi bersama membosankan oleh arus melalui eksitasi berliku dan jika isolasi rusak dan kontak listrik dibuat untuk inti, arus besar dapat mengalir yang bisa merusak inti atau menyebabkan cedera

2. Periksa bahwa SPU dan Chattock (s) berfungsi dengan benar dengan menggunakan Unit Kalibrasi

3. Biarkan SPU pada biaya untuk setidaknya 16 jam sehingga baterai terisi penuh untuk ujian jika operasi dari pasokan AC tidak mungkin. Perhatikan bahwa jika tes ini diharapkan akan cukup singkat, masa pakai baterai tidak mungkin cukup untuk tes penuh. Hal ini dimaksudkan untuk penggunaan jangka pendek, misalnya ketika dibawa ke inti untuk menyelidiki kesalahan dicurigai

- Memeriksa Core numbering slot

1. Pastikan bahwa kondisi kerja yang aman ada di wilayah kerja

2. Pastikan tidak ada benda logam telah ditinggalkan di dalam membosankan karena ini dapat menyebabkan kerusakan lengkung ke inti ketika arus eksitasi diaktifkan

3. Periksa secara visual inti dan menandai setiap kawasan yang rusak

4. Perbaiki pita perekat putih di sekitar bore pada akhir kerja, sebelum dimulainya laminasi, dan nomor slot (tidak gigi). Jika produsen sistem Slot penomoran tidak diketahui, slot pukul 12 biasanya ditandai sebagai nomor satu. Slot lainnya kemudian nomor searah jarum jam. (Metode penomoran ini tentu saja opsional)

Pastikan bahwa gulungan stator telah benar terputus dan jika diperlukan, dibumikan sesuai dengan semua prosedur keselamatan yang berlaku. Dalam rangka untuk menghindari resiko dari arus induksi kebetulan beredar di gulungan stator oleh eksitasi, adalah lebih baik bahwa gulungan terputus di satu ujung dan dibumikan di lain (biasanya netral). Jika karena keadaan dan prosedur perlu bahwa gulungan dibumikan di kedua ujungnya, kemudian memastikan bahwa semua 3 gulungan yang identik dibumikan. Pastikan bahwa rute koneksi ikatan bumi antara ujung tidak mengelilingi kabel inti atau eksitasi untuk mencegah risiko arus liar yang diinduksi.

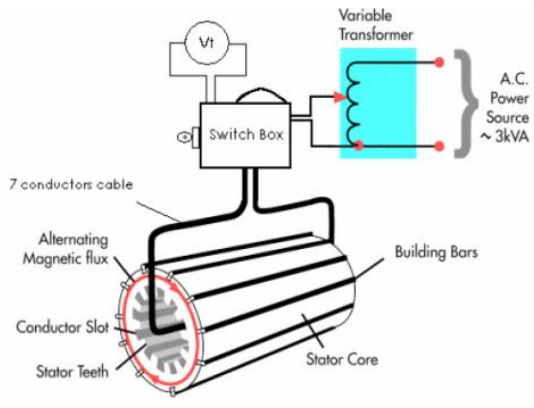

Gambar 9. Eksitasi winding.

Eksitasi berliku terdiri dari beberapa putaran (6 dalam Evolution kit) dari kabel yang digunakan ini sedang, luka di sekitar casing stator dan melalui core. Standar EL CID Turbo Switched Eksitasi kit dapat digunakan jika dimensi dan rating yang cocok untuk uji mesin-lihat Eksitasi Sistem Manual. Untuk hasil yang optimal dan konsisten adalah penting bahwa berliku didukung dekat dengan pusat core sepanjang penuh stator, termasuk akhir-berliku. Sebuah terpisah, konduktor ketujuh adalah bagian dari kabel eksitasi dan digunakan untuk mengukur tegangan induksi. Dalam situasi di mana posisi sentral dari berliku tidak praktis (misalnya. Di mana rotor tidak sepenuhnya dihapus) efek dari posisi eksitasi berliku harus diperhitungkan ketika mengevaluasi hasil tes. Bolak arus yang mengalir melalui eksitasi berliku menginduksi tegangan sepanjang inti dan itu adalah tegangan ini yang menyebabkan arus mengalir melalui daerah yang rusak dari inti. Tegangan eksitasi standar (diukur dengan jejak berkelok-kelok) untuk tes CID EL harus 4\% dari tegangan dinilai diinduksi sepanjang inti dalam operasi normal. Kesalahan arus yang mengalir dalam inti stator hampir sebanding dengan tegangan eksitasi di wilayah $4 \%$ eksitasi. Oleh karena itu, jika tidak mungkin atau nyaman untuk mendapatkan $4 \%$ dari tegangan pengenal, nilainilai antara 2 dan $10 \%$ dapat digunakan asalkan arus kesalahan diukur dengan EL CID skala sesuai.

Untuk tingkat yang benar eksitasi perlu untuk mengetahui nilai tegangan rms yang dinilai sepanjang panjang tunggal inti, $\mathrm{V} r$ untuk generator. Ini diberikan oleh:

$$
\text { - V r }=\frac{\text { Vpp }}{2 \sqrt{3} . k . t p} \ldots . . .(1)
$$

Dimana :

V pp : adalah tegangan fase-ke-fase.

$\mathrm{t} \mathrm{p}$ : adalah jumlah putaran dalam seri per fase. yaitu. jumlah konduktor dalam seri di setiap fase adalah $2 \mathrm{t} p$. dan K mewakili penyebaran gabungan dan faktor kerja. Sebuah nilai 0,92 dapat digunakan untuk semua generator. 
RESISTOR (elektRonika kEndali telekomunikaSI tenaga liSTrik kOmputeR) Vol. 1 No. 2 e-ISSN : 2621-9700, p-ISSN : 2654-2684

Oleh karena itu standar $4 \%$ eksitasi, diukur dengan jejak berliku, diberikan oleh:

$\mathrm{V}=\mathrm{T} 0.04 \mathrm{~V} \mathrm{r}$.

Contoh Perhitungan.

Pertimbangkan $23 \mathrm{kV}$, tiga fase, 660MW generator dengan 42 slot, yaitu. 14 slot per fase. Setiap slot berisi dua bar konduktor dengan dua gulungan terhubung secara paralel. Oleh karena itu $\mathrm{t}$ $\mathrm{p}=7$ seri ternyata per fase. Sejak V pp $=23 \mathrm{kV}, \mathrm{V} \mathrm{r}=$ $1031 \mathrm{~V}$ dan standar $4 \%$ eksitasi $\mathrm{V}=\mathrm{T} 41.2 \mathrm{~V}$.

Catatan: nilai dihitung untuk V T untuk $50 \mathrm{~Hz}$ dua kutub generator 200MW atau lebih besar pada $4 \%$ dari tegangan biasanya sesuai dengan sekitar $5 \mathrm{~V}$ / $\mathrm{m}$ panjang inti. Nilai sebenarnya dari $41.2 \mathrm{~V}$ Oleh karena itu konsisten karena inti stator dari generator 660MW adalah $7.5 \mathrm{~m}$ panjang. Namun nilai-nilai V / $\mathrm{m}$ untuk mesin di mana dimensi radial tidak sama proporsional (generator empat tiang turbo, motor, atau generator hidro, misalnya) mungkin substansial berbeda dan $5 \mathrm{~V} / \mathrm{m}$ tidak boleh digunakan sebagai kriteria umum

Persamaan (1) juga berlaku untuk motor dan harus, jika mungkin, digunakan untuk menghitung tegangan eksitasi. Hal ini sering sulit, namun karena insinyur tes tidak tahu jumlah seri ternyata per fase dan nilai-nilai untuk $\mathrm{K}$ mungkin lebih bervariasi. Alternatifnya adalah dengan menggunakan persamaan:

$$
\mathrm{V} \mathrm{r}=2 \cdot \text { Field B }
$$

dimana

$\mathrm{f}$ : adalah frekuensi.

$\mathrm{L}$ :adalah panjang inti dalam meter.

$\mathrm{D}$ :adalah kedalaman jarak dalam meter dari dasar slot ke belakang inti.

B : adalah mean rms kerapatan fluks (Tesla)

Inti dimensi pengukuran 1 dan d ditunjukkan pada Gambar

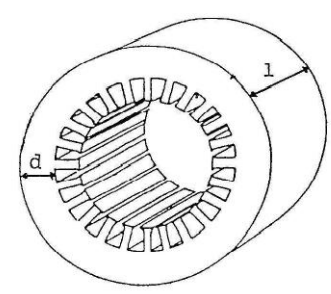

Gambar 10. Pengukuran perhitungan eksitasi tegangan.

Kebanyakan mesin memiliki mean rms kerapatan fluks $\mathrm{B} \approx 0.9 \mathrm{~T}$, meskipun bisa ada variasi khas $\pm 10 \%$ karena perbedaan fraksi volume baja di inti, dll. Oleh karena itu untuk pengukuran dalam meter dinilai rms tegangan per giliran diberikan oleh:
$\mathrm{V} \mathrm{r} \approx 5,65$ Field ... (2) dan tegangan uji 4\%:

$\mathrm{V} \mathrm{T} \approx 0,226$ Field $\ldots$ (3)

Jika 1 dan d diukur dalam inci maka persamaan 3 menjadi

$\mathrm{V} \mathrm{T} \approx 0.000146$ Field $\ldots$.. (3a)

- $\quad$ Step - by step pengujian ELCID

1. Siapkan Mesin

a. Tanah / groundkan belitan stator dari satu ujung saja, tidak memperpendek terminal ujung

b. Lepaskan benda logam dalam stator

c. daerah yang rusak Mark, jika ada yang terlihat

d. Nomor slot stator pada kedua ujung inti

2. Perhitungan

e. Evaluasi mesin stator turn-per-fase dalam seri berliku:

f. $T p=($ Slots $x$ Belitan pada slot $x$ Ternyata di Winding ) / ( 3 x Parallels $\mathrm{x} 2$ )

g. Hitung tunggal tegangan turn (rumus disederhanakan):

h. $\mathrm{Vt}($ volt $)=(12,56 \mathrm{x} \mathrm{Vp}-\mathrm{p}($ kilovolt $)) / \mathrm{Tp}$

i. Jika rincian berliku tidak dikenal menggunakan metode geometri: $\mathrm{Vt}($ volt $)=0,226 \times \mathrm{Hz} \times 1($ meter ) $\mathrm{x} \mathrm{d}$ ( meter )

j. Hitung ampere-ternyata persyaratan perkiraan: Pada $=(2-25) \times \mathrm{C}$, di mana $\mathrm{C}=\pi \times(\mathrm{OD}+$ $\mathrm{SD})$ / 2 ; OD - diameter luar stator inti; SD diameter inti stator di bawah slot (Biasanya, untuk mesin menengah Pada $=8-12 \mathrm{C}$, namun di motor Pada bisa setinggi 25C)

k. perkiraan jumlah bergantian untuk eksitasi berliku (perlu diingat turbo Peringkat kabel eksitasi: 4-6 ternyata @ 20A maksimal, 2-3 ternyata@32A maksimum)

1. Periksa saat ini diharapkan eksitasi berliku Iw = $\mathrm{A}$ - bergiliran / Nw ; nw - jumlah putaran $=>\mathrm{Nw}$ = A-bergiliran / Iw (Sebuah) $\mathrm{Vw}=\mathrm{Vt} \times \mathrm{Nw}$ tingkat eksitasi pasokan tegangan (b) Tentukan jumlah putaran mempertimbangkan (a) dan (b) kebutuhan listrik Eksitasi: VA $=$ Vw x Iw

m. Verifikasi perhitungan dengan menggunakan Elan built-in kalkulator

n. Verifikasi perhitungan dengan membagi Vt lebih stator panjang inti dalam meter Hasilnya harus dalam kisaran:

Kecil - motor menengah 0,7-2 V/m

$>$ Menengah - besar dua generator tiang turbo $\sim 4$ sampai $6 \mathrm{~V} / \mathrm{m}$

$>$ generator hidro $\sim 1$ sampai $3 \mathrm{~V} / \mathrm{m}$

1. Menyiapkan dan menginstal sistem eksitasi

$>$ Gunakan tali dan / atau blok dukungan kayu ke pusat gulungan eksitasi

2. Membuat semua koneksi (ELCID dan power supply) 
RESISTOR (elektRonika kEndali telekomunikaSI tenaga liSTrik kOmputeR) Vol. 1 No. 2 e-ISSN : 2621-9700, p-ISSN : 2654-2684

3. mengkalibrasi Chattocks atau Y - sumbu (ingat untuk mengatur frekuensi sesuai dengan lokal frekuensi)

4. Sesuaikan Trolley dengan kelengkungan stator bore dan rentang Slot

5. Hidupkan power supply dan memantau Vt dan Iw

6. Mengkalibrasi jarak atau X - sumbu, dengan sinyal referensi yang tersedia

7. Mengkalibrasi FASE dengan Trolley di inti

8. Verifikasi FASE ditampilkan nilai dalam beberapa poin stator:

9. Seharusnya FASE $=$ Iw $/ \mathrm{N}$ slots $+10 \div 20 \%$ ( tergantung pada Slot / wedge rasio lebar dan bahan inti kerugian)

10. Menghubungkan computer

11. panjang ukuran inti dan besi langkah

12. Set parameter uji dalam perangkat lunak

13. Uji coba

14. Melakukan tes

15. Simpan dan backup data uji

\section{HASIL DAN ANALISA}

Tabel 1. Spesifikasi generator 1 .

\begin{tabular}{|c|c|}
\hline MANUFACTURE & NISHISHIDA \\
\hline RATED VOLTAGE & $6.3 \mathrm{KV}$ \\
\hline CORE LENGTH & $0.77 \mathrm{METERS}$ \\
\hline $\begin{array}{c}\text { SERIES TURN PER } \\
\text { CIRCUIT }\end{array}$ & 28 \\
\hline YEAR MANUFACTURE & 2000 \\
\hline RATED POWER & $5 \mathrm{MW}$ \\
\hline NUMBERS SLOT & 84 \\
\hline TEST SEQUENCE & FIRST \\
\hline
\end{tabular}

Tabel 2. Generator 2.

\begin{tabular}{|c|c|}
\hline MANUFACTURE & NISHISHIDA \\
\hline RATED VOLTAGE & $6.3 \mathrm{KV}$ \\
\hline CORE LENGTH & $0.89 \mathrm{METERS}$ \\
\hline $\begin{array}{c}\text { SERIES TURN PER } \\
\text { CIRCUIT }\end{array}$ & 28 \\
\hline YEAR MANUFACTURE & 2004 \\
\hline RATED POWER & $5 \mathrm{MW}$ \\
\hline NUMBERS SLOT & 78 \\
\hline TEST SEQUENCE & FIRST \\
\hline
\end{tabular}

Tabel 3. Generator 3.

\begin{tabular}{|c|c|}
\hline MANUFACTURE & NISHISHIDA \\
\hline RATED VOLTAGE & $6.3 \mathrm{KV}$ \\
\hline
\end{tabular}

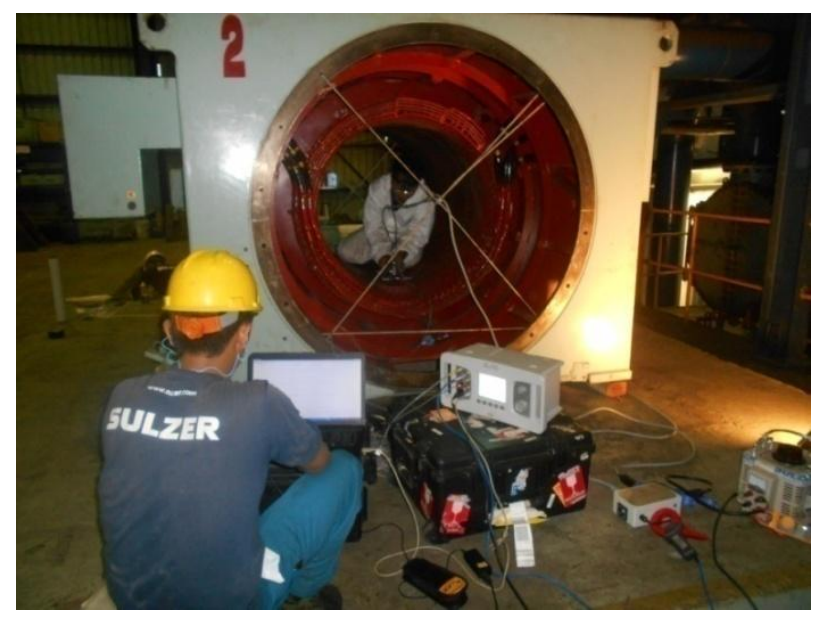

Gambar 11. Generator.

Tabel 4. Daftar alat yang digunakan.

\begin{tabular}{|c|c|}
\hline NO & NAMA ALAT \\
\hline 1 & MEJA \\
\hline 2 & KERTAS \\
\hline 3 & SPIDOL PUTIH \\
\hline 4 & TALI NON LOGAM \\
\hline 5 & KAYU \\
\hline 6 & SENTER \\
\hline 7 & LAPTOP \\
\hline 8 & ELCID \\
\hline 9 & TANG AMPERE \\
\hline 10 & AVO METER \\
\hline 11 & REGULATOR TEGANGAN \\
\hline 12 & MANUAL TROLLEY \\
\hline 13 & CHATTOCK \\
\hline 14 & MANUAL SWITCBOX / TERMINAL \\
\hline 15 & LAMPU PENERANGAN \\
\hline
\end{tabular}

- Perhitungan eksitasi tegangan pada generator GENERATOR 1.2.dan 3

Dik : Vpp $=6.3 \mathrm{Kv}$

$\mathrm{Tp}=28$ Seri Perfase

Dit : Vr........? 
RESISTOR (elektRonika kEndali telekomunikaSI tenaga liSTrik kOmputeR) Vol. 1 No. 2 e-ISSN : 2621-9700, p-ISSN : 2654-2684

Jawab :

$$
\begin{aligned}
\mathrm{Vr} & =\frac{\mathrm{Vpp}}{2 \sqrt{3} \cdot \mathrm{K.tp}} \\
\mathrm{Vr} & =\frac{6,3 \mathrm{Kv}}{2 \sqrt{3.0 .92 .28}} \\
\mathrm{Vr} & =\frac{6,300 \mathrm{Kv}}{89.1296} \\
\mathrm{Vr} & =70.68 \mathrm{v} \\
\mathrm{V} & =\mathrm{T} 0.04 \times \mathrm{Vr} \\
\mathrm{V} & =0.04 \times 70.68 \mathrm{~V} \\
\mathrm{~V} & =2.82 \mathrm{v}
\end{aligned}
$$

- Langkah langkah pemasangan eksitasi dan pengujian

1. Menyiapkan Dan Menginstal Sistem Eksitasi

Dengan cara Menggunakan Tali atau kayu untuk mendukung sistem Eksitasi

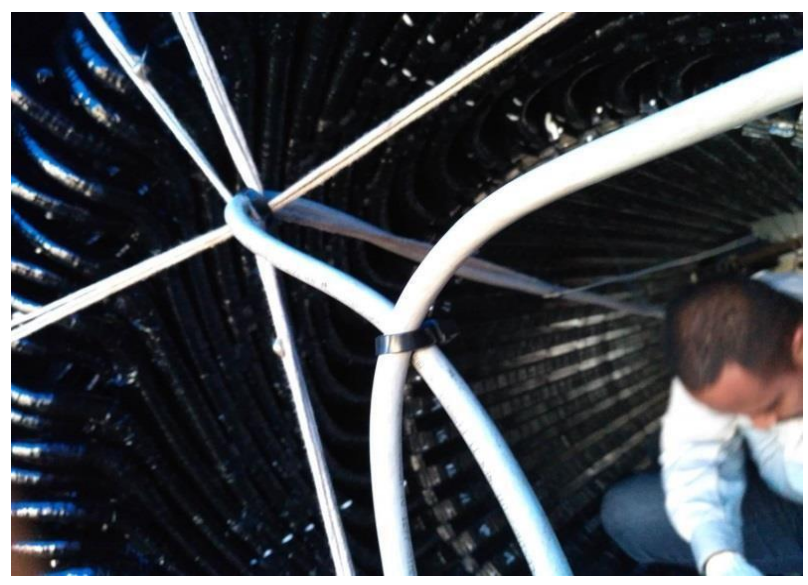

Gambar 12. Pemasangan kabel eksitasi.

2. Membuat sistem koneksi ELCID

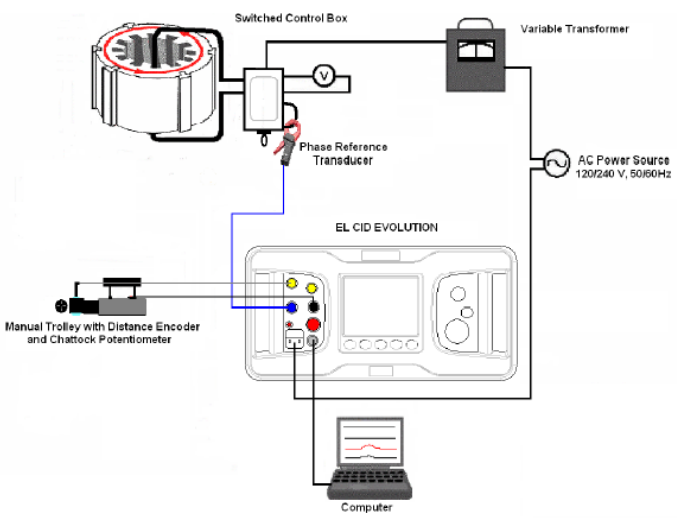

Gambar 13. Sistem koneksi ELCID.

\section{Menkalibrasi chattock}

Input Chattock Sinyal untuk Input 1 atau 2 dapat dikalibrasi. Pilih nilai Kalibrasi sesuai dengan menggunakan ^, Softkeys v ,. Jika nilai diketahui, maka nilai\% dapat langsung mengatur pada kontrol Rotary, dan dikonfirmasi dengan tombol OK. Namun dianjurkan bahwa Chattocks selalu dikalibrasi setiap kali penggunaan dengan unit Kalibrasi, karena hal ini memberikan cek dari fungsi yang benar dari sistem, dan juga akan memungkinkan untuk fakta bahwa kalibrasi Chattock dapat melayang dengan waktu dan memakai. Dalam hal ini, dipilih nilai Kalibrasi, tekan Softkey label Kalibrasi, yang akan menyebabkan layar Signal Kalibrasi

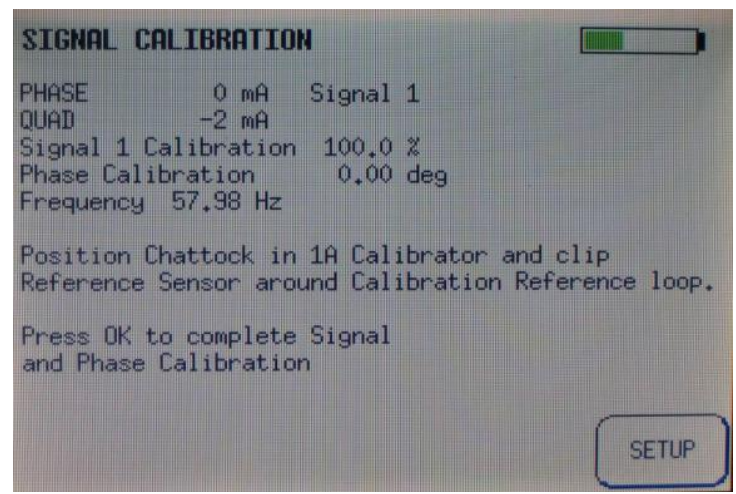

Gambar 14. Sinyal kalibrasi.

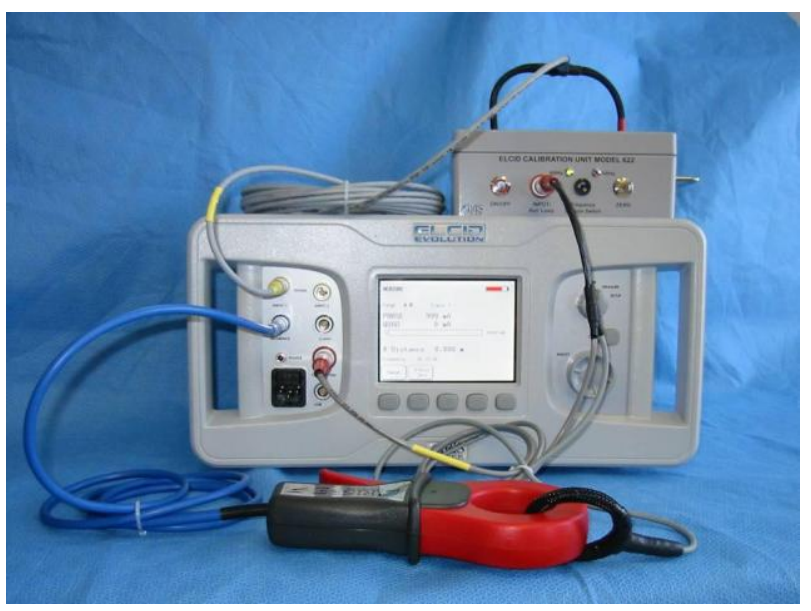

Gambar 15. Koneksi kalibrasi.

4. Menkalibrasi fase

EL CID Evolution menganalisa Chattock Signal menjadi di-Phase dan sinyal Quadrature sehubungan dengan sinyal Referensi. Karena sinyal Referensi diambil dari perangsangan saat digunakan untuk menginduksi fluks tes di inti, kesalahan fase dalam mendeteksi sinyal ini sehubungan dengan mmf diinduksi dapat mempengaruhi sinyal indikasi kesalahan, yaitu. sinyal Quad. Dalam rangka untuk memungkinkan kesalahan tersebut untuk dikompensasikan, maka Referensi dapat diimbangi dengan nilai Tahap Kalibrasi dalam derajat, itu adalah jumlah yang analisis internal di muka dari masukan Referensi. 


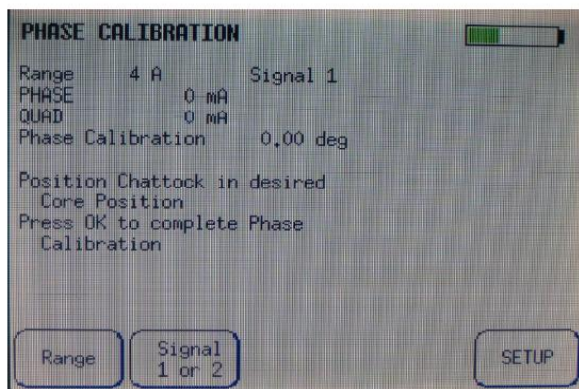

Gambar 16. Sinyal kalibrasi phase.

5. Menkalibrasi $X-$ Axis

Untuk mengkalibrasi X-Axis, menghubungkan RIV / Trolley ke EL CID seperti untuk pengujian. Dasar dari kalibrasi adalah untuk memindahkan RIV / Trolley jarak diketahui dimana SPU kemudian menghitung nilai ppm. Menandai uji coba di bore stator dari satu atau lebih meter. Pada inti lagi, itu diinginkan untuk mengkalibrasi selama lebih dari satu meter untuk meningkatkan akurasi. Pada inti pendek yang kurang dari $1 \mathrm{~m}$ jarak jauh dapat dikalibrasi bukan di atas meja atau lantai.

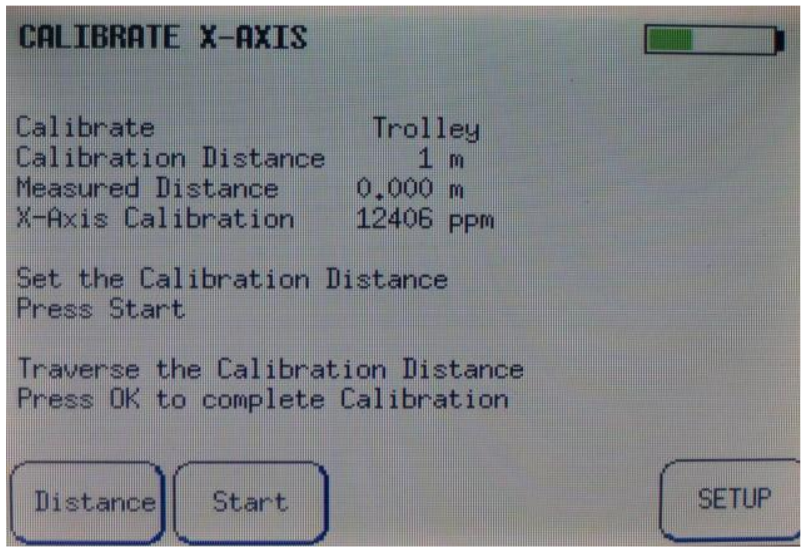

Gambar : Sinyal kalibrasi X - AXIS

6. Menyesuaikan Trolley

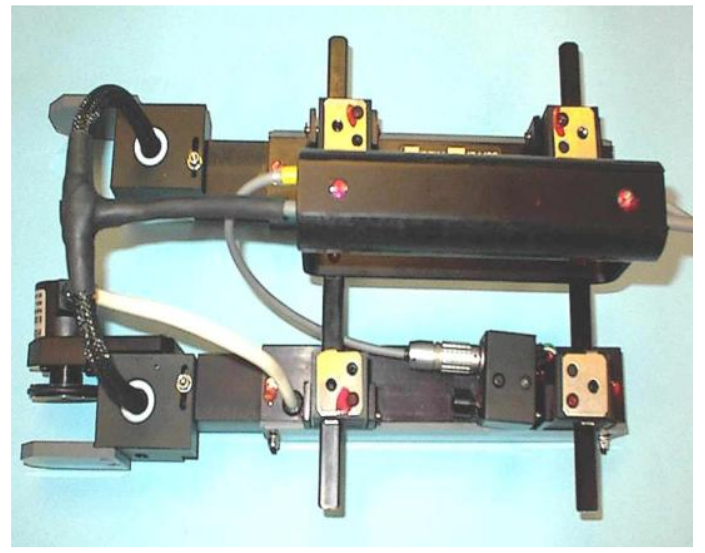

Gambar 17. Menyesuaikan trolley.

Hubungkan Trolley Manual untuk input EL CID Evolution SPU X-Axis dengan kabel yang disediakan, dan sinyal jarak operasi dari tombol. Perhatikan bahwa konektor adalah terpasang kuat antara bagian Trolley, dan mereka mungkin harus sedikit dipisahkan untuk memungkinkan konektor untuk melewati antara mereka. Trolley harus dilengkapi dengan rentang Chattock terkecil, dengan memperhatikan pitch gigi stator untuk diuji, yang tidak menempatkan ketegangan pada Chattock

\section{Menghubungkan ke computer / laptop}

Yang pertama dilakukan adalah pemasangan software Elan Analysis bila pada pc / laptop belum terpasang program Software lalu bila sudah terpasang dimulai dengan memilih menu file pada folder baru untuk membuat job name yang akan di analisa pada folder lalu mulai memasukan calculate / set parameter setting pada data yang disediakan pada program dan mensetting slot track unttuk mengeprint hasil data

8. Measure

Untuk masuk kedalam mode measure pindahkan switch yang ada di kontrol Spu yang ada di sebelah kanan lalu pindahkan kearah measure

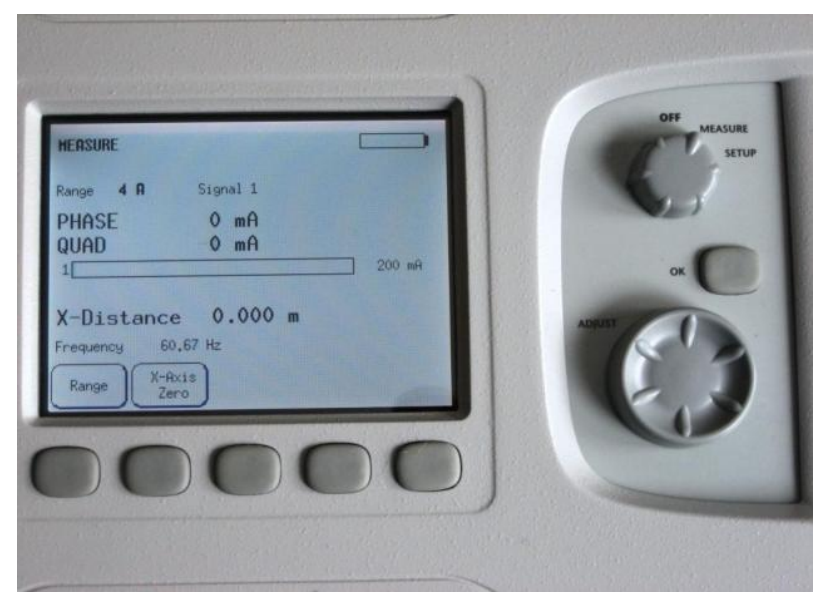

Gambar 18. Measure.

Dalam mode Ukur, kontrol instrumen Range, yang dapat dipilih dengan Rentang Softkey dari 0.4A, 4.0A 40A Rentang harus ditetapkan setelah menempatkan Chattock dalam inti, dan mencatat nilai FASE (yang biasanya dominan). Mengaturnya pada rentang yang memiliki kapasitas yang seuai untuk pengukuran. Misalnya, di sebagian besar core turbogenerator, nilai FASE dari 1-3A yang biasa, dan di sini kisaran 4A akan sesuai. Dalam beberapa motor yang lebih kecil dan lebih kecil hidro-generator, di mana sinyal FASE tidak boleh melebihi $400 \mathrm{~mA}$, 
RESISTOR (elektRonika kEndali telekomunikaSI tenaga liSTrik kOmputeR) Vol. 1 No. 2 e-ISSN : 2621-9700, p-ISSN : 2654-2684

maka rentang $0.4 \mathrm{~A}$ akan memberikan resolusi yang lebih baik

9. Calculate parameter uji

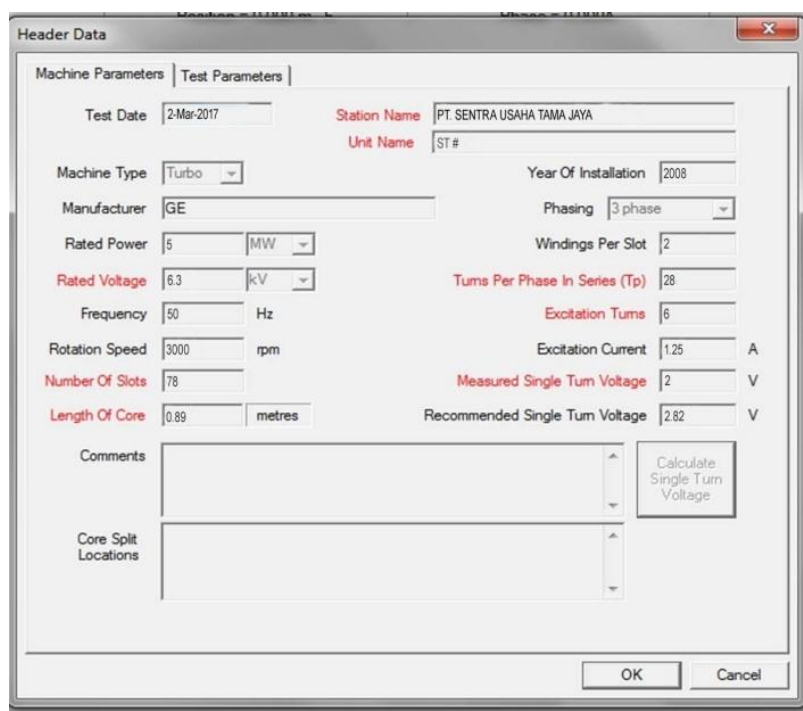

Gambar 19. Header data.

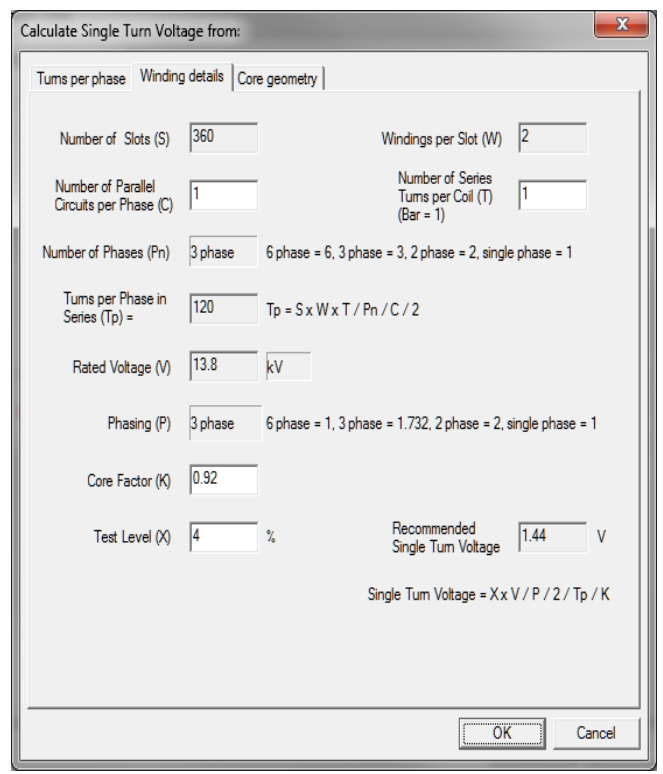

Gambar 20. Calculation voltage.

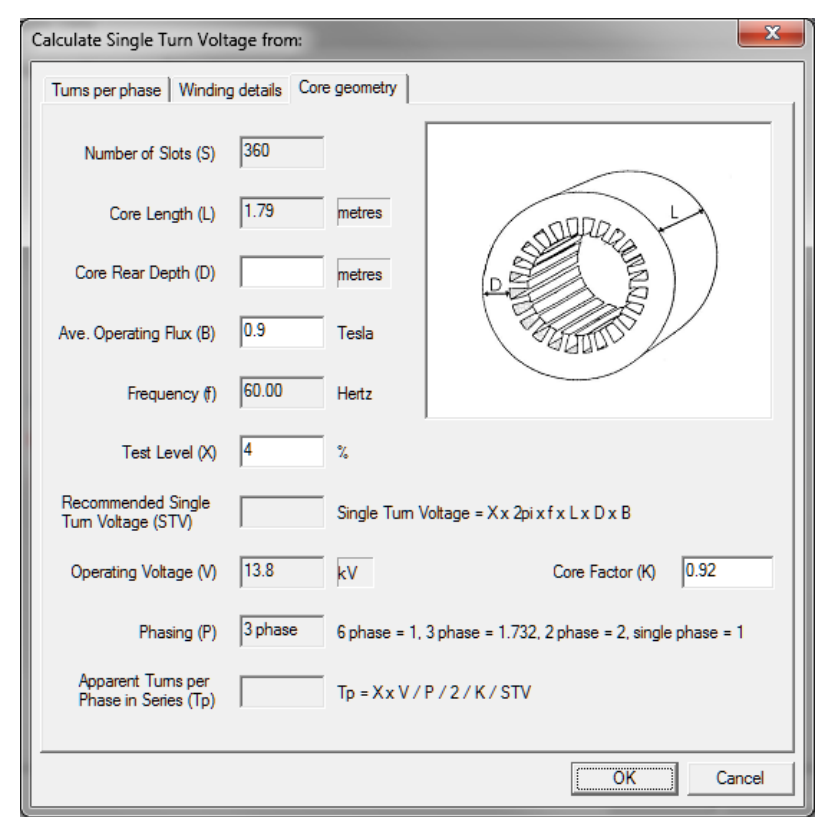

Gambar 21. Contoh calculate parameter uji.

- Hasil Pengetesan core iron

\section{$>$ Generator 1}

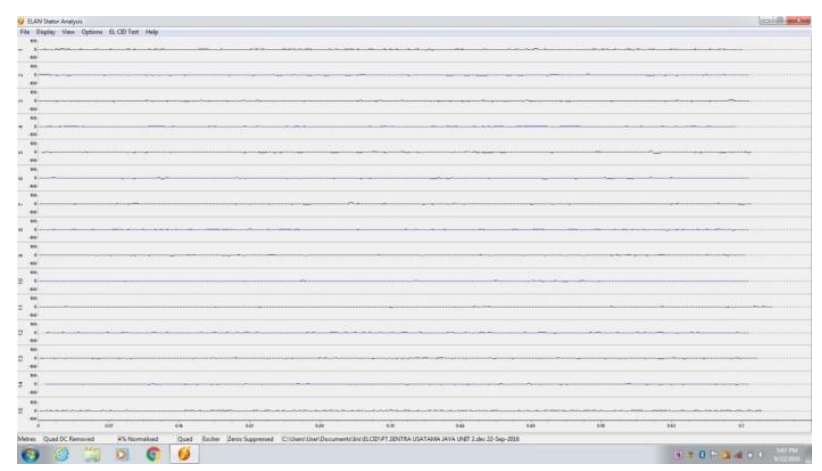

Gambar 22. Slot $1-15$.

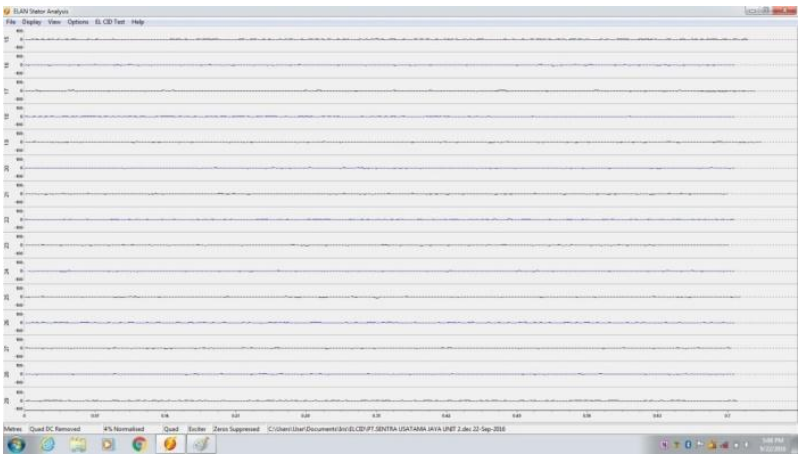

Gambar 23. Slot $15-29$. 
RESISTOR (elektRonika kEndali telekomunikaSI tenaga liSTrik kOmputeR) Vol. 1 No. 2 e-ISSN : 2621-9700, p-ISSN : 2654-2684

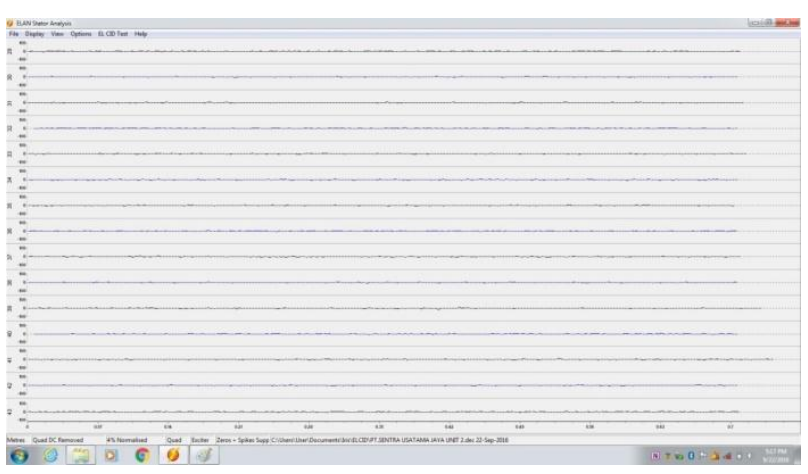

Gambar 24. Slot 29 - 43.

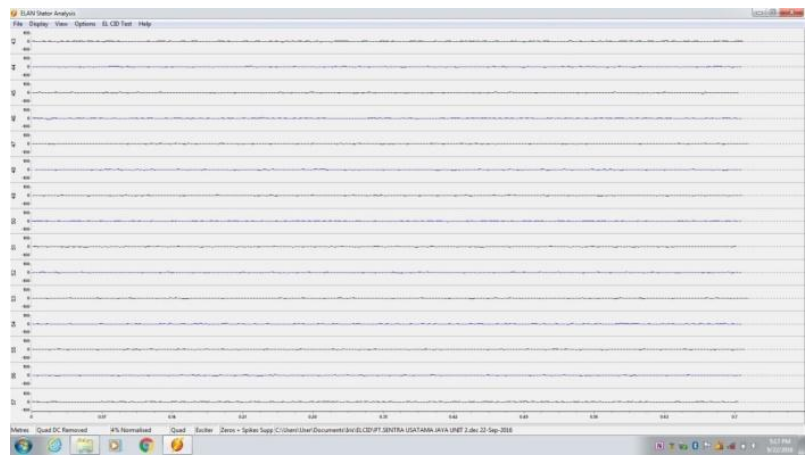

Gambar 25. Slot $43-57$.

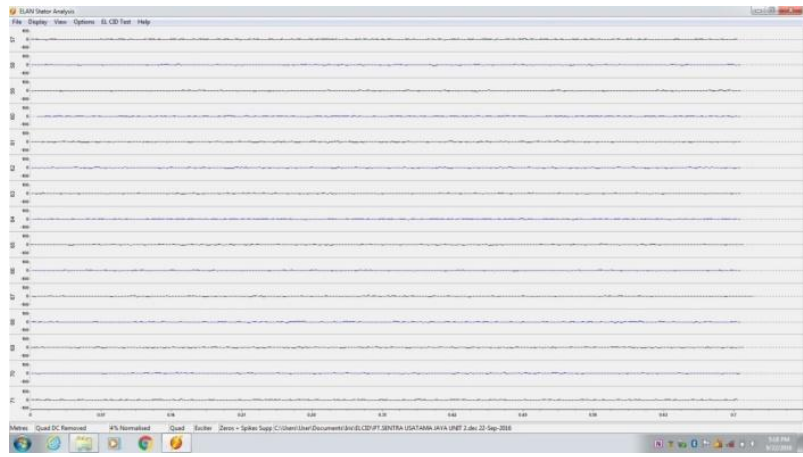

Gambar 26. Slot $57-71$.

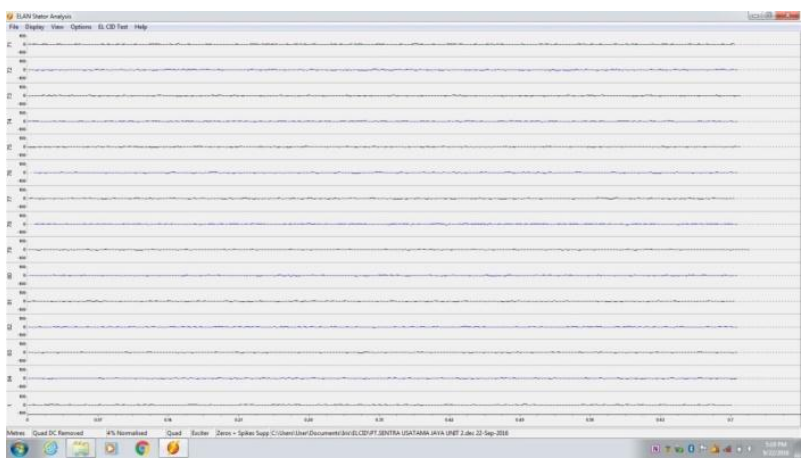

Gambar 27. Slot $71-1$.

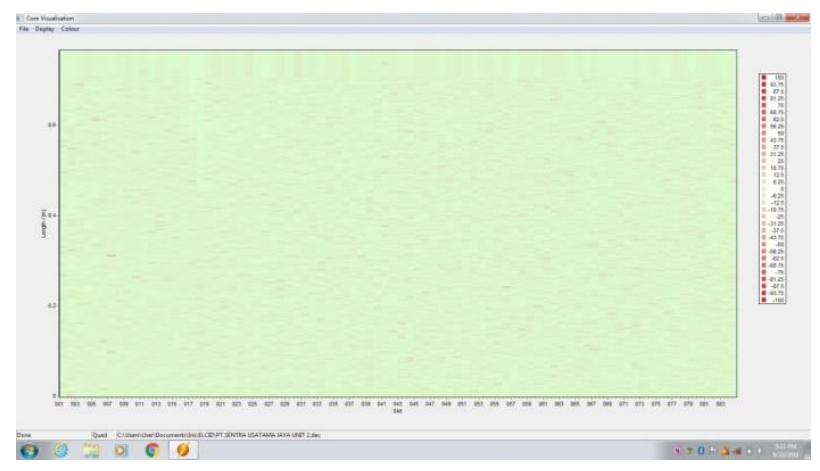

Core visualization

\section{GENERATOR 2}

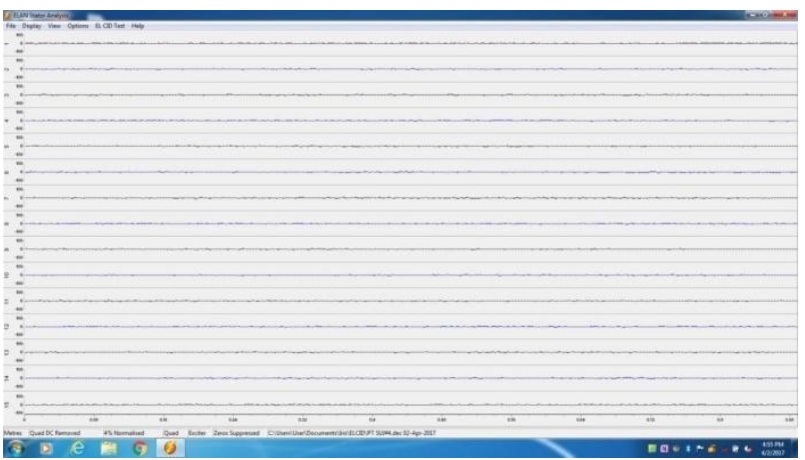

Gambar 28. Slot $1-15$.

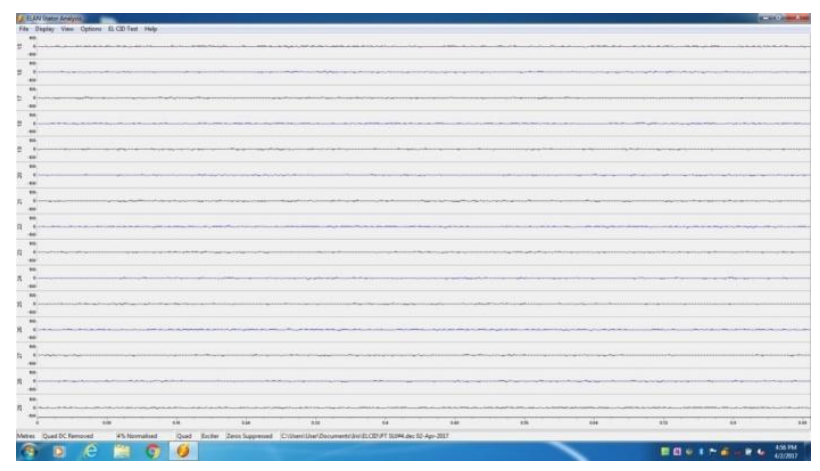

Gambar 29. Slot 15 - 29.

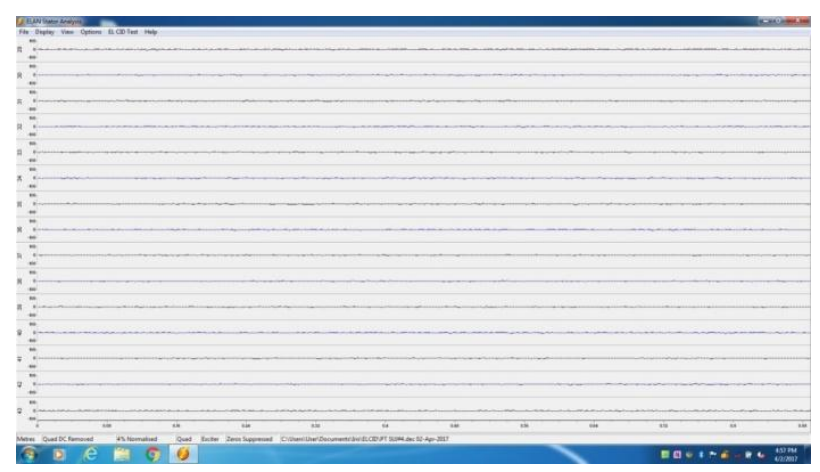

Gambar 30. Slot 29 - 43. 
RESISTOR (elektRonika kEndali telekomunikaSI tenaga liSTrik kOmputeR) Vol. 1 No. 2 e-ISSN : 2621-9700, p-ISSN : 2654-2684

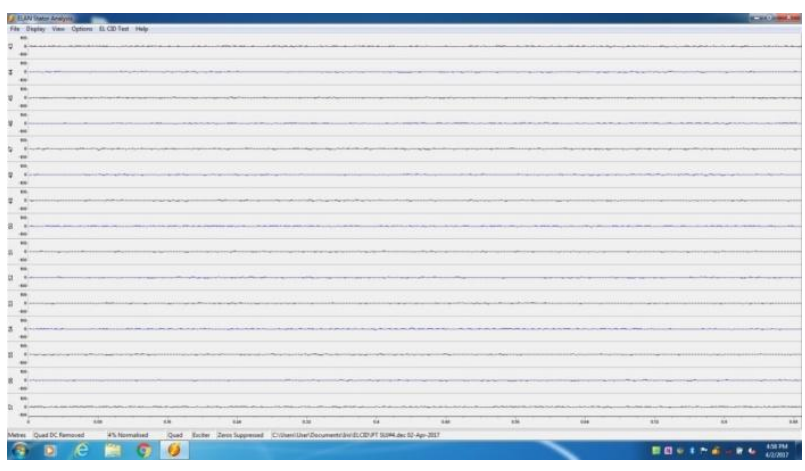

Gambar 31. Slot $43-57$.

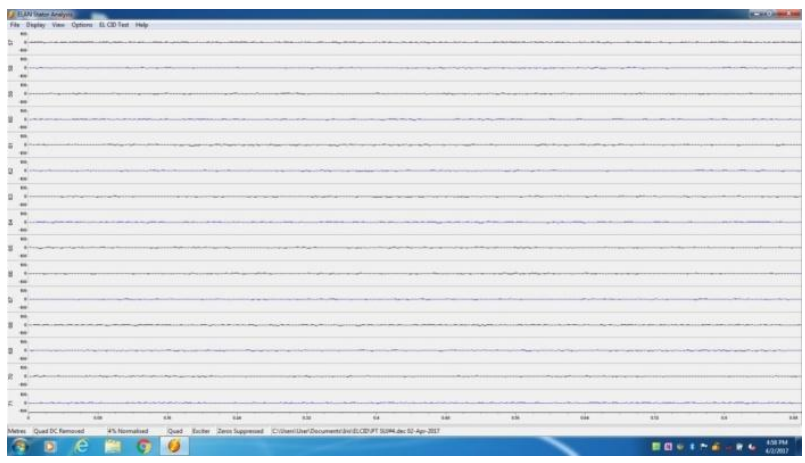

Gambar 32. Slot $57-71$.

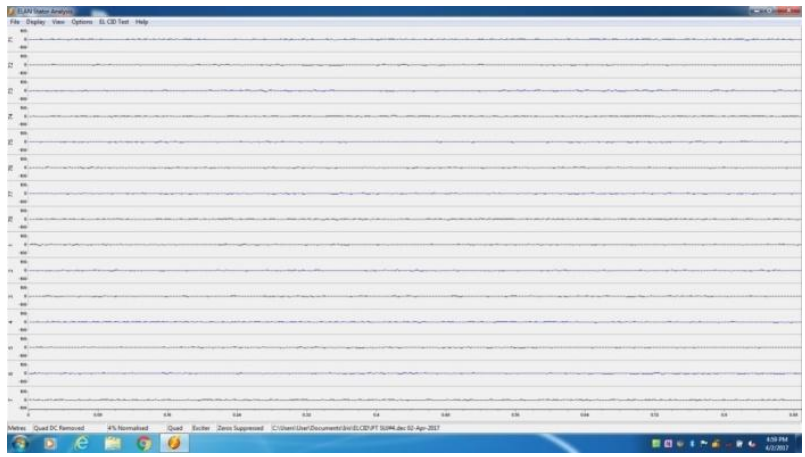

Gambar 33. Slot $71-1$.

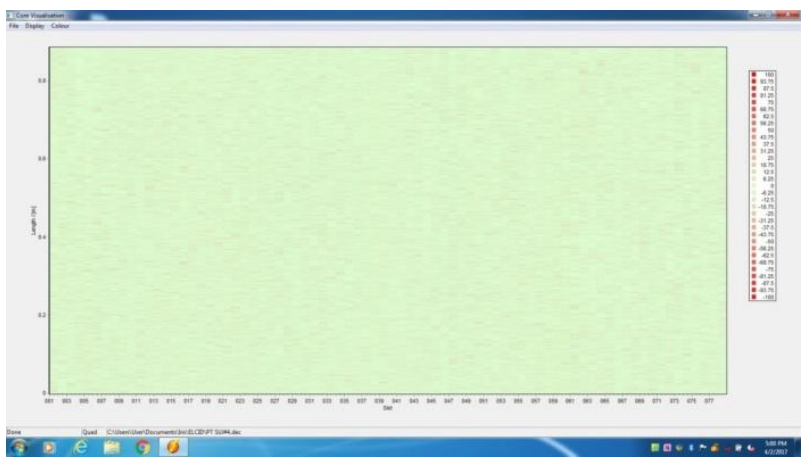

Gambar 34. Core visualization.

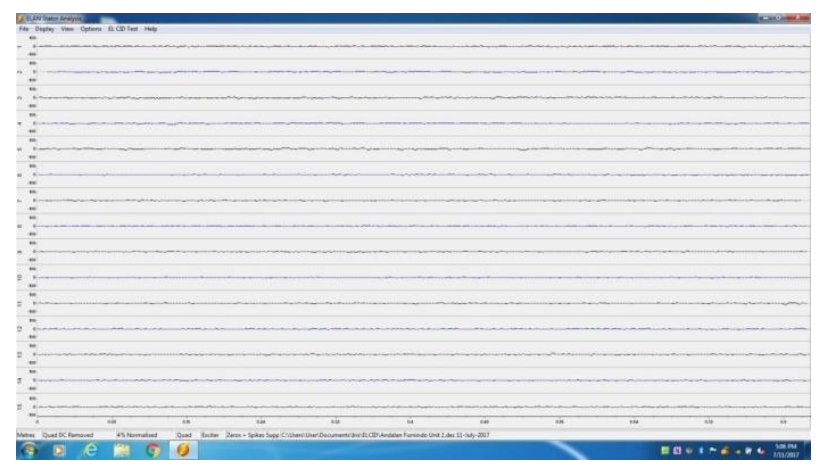

Gambar 35. Slot $1-15$.

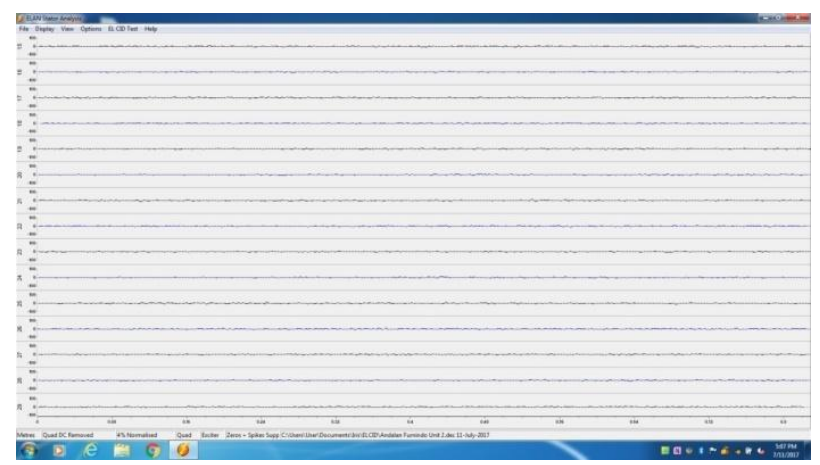

Gambar 36. Slot $15-29$.

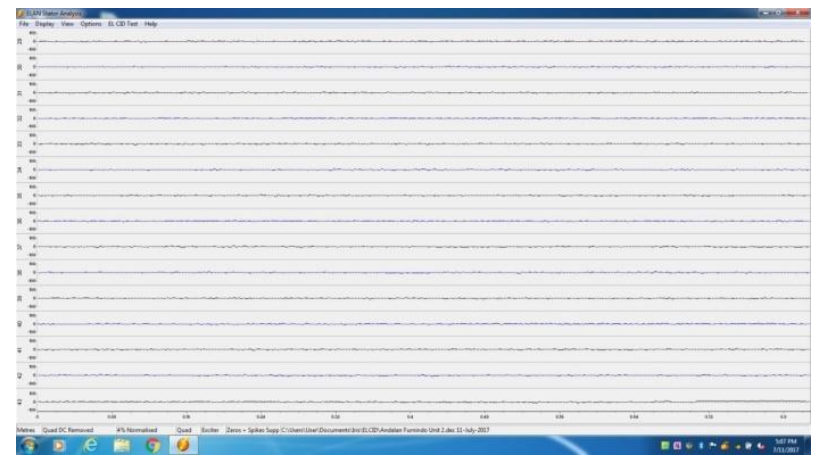

Gambar 37. Slot 29 - 43.

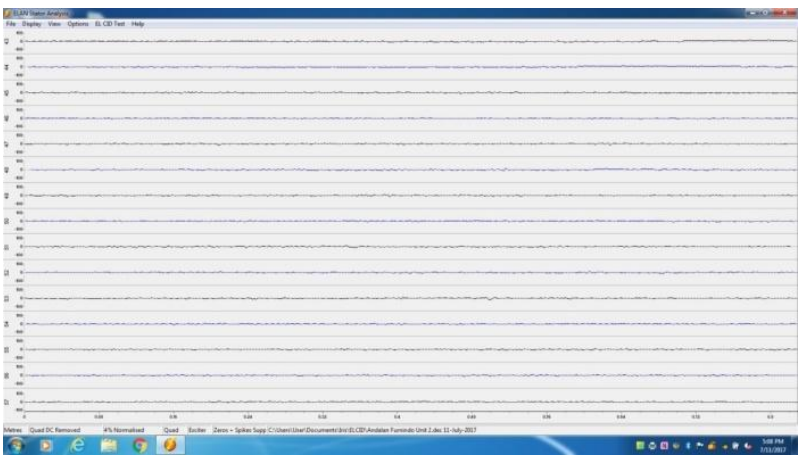

Gambar 38. Slot $43-57$. 
RESISTOR (elektRonika kEndali telekomunikaSI tenaga liSTrik kOmputeR) Vol. 1 No. 2 e-ISSN : 2621-9700, p-ISSN : 2654-2684

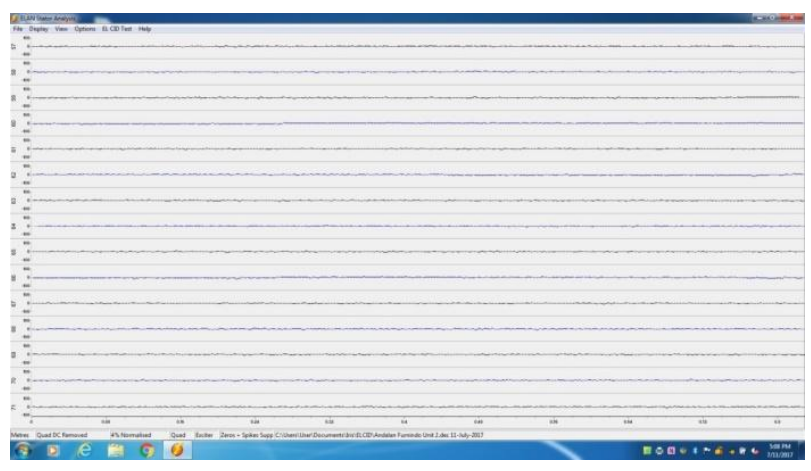

Gambar 39. Slot $57-71$.

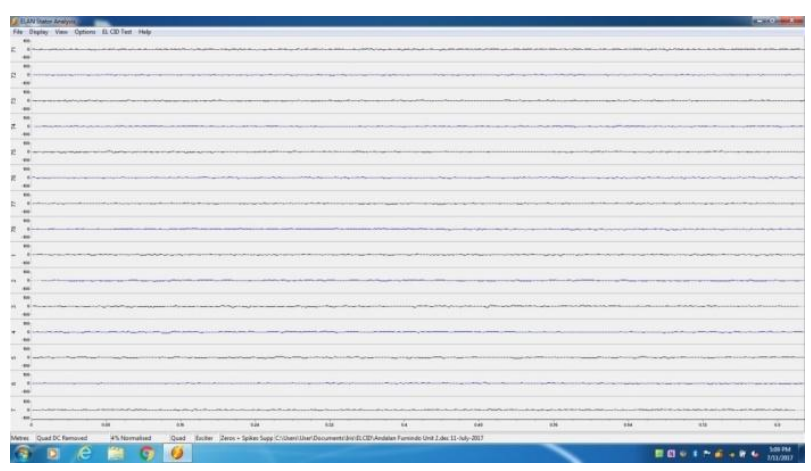

Gambar 40. Slot $71-1$.

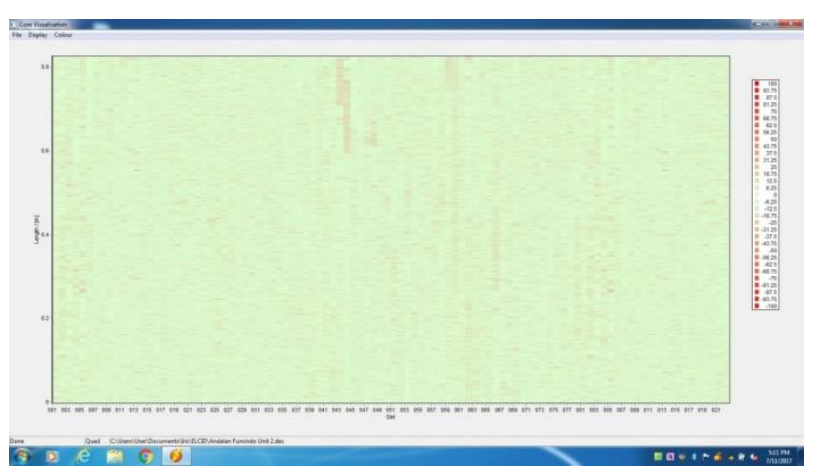

Gambar 41. Core visualization.

\section{KESIMPULAN}

Dari hasil penelitian diatas dapat disimpulkan bahwa suatu core iron stator generator perlu untuk dites core agar dapat mengetahui kondisi isolasi pada kepingan kepingan lapisan baja pada core dalam kondisi baik atau tidak akibat gerakan mekanik yang berlebih pada stator yang dapat merusak core pada stator dan bisa menghambat kinerja generator pada saat beroperasi untuk itulah saya meneliti bagaimana kondisi kelayakan pada core iron stator dengan 3 generator dengan memiliki daya yang sama dan tahun pemasangan yang berbeda dan setelah saya teliti / tes ternyata kondisi pada generator 1,2 , dan 3 diproleh hasil data atau kondisi core iron masih dalam keadaan layak atau masih berfungsi dengan baik karena tidak terlihat panas yang berlebih pada track atau jalur slot pada stator di generator 1,2 , dan 3 yang bisa menghambat generator beroperasi maksimal yang bisa mengakibatkan core iron panas / hot spot adalah pertama ledakan pada guluungan yang dapat mengakibatkan slot pada core pecah ato rusak dan dapat menghilangkan lapisan isolasi pada core iron kedua gesekan rotor yang mengenai gap pada slot core yang diakibatkan oleh rusaknya bearing / mekanikal yang dapat membuat core lecet / baret yang bisa mengakibatkan core panas

\section{DAFTAR PUSTAKA}

[1] G. C. Stone, E. A. Boulter, I. Culbert, H. Dhirani, and H. Lane, "Electrical Insulation for Rotating Machines-Design, Evaluation, Aging, Testing, and Repair," IEEE Electrical Insulation Magazine, vol. 20, no. 3, p. 1, 2004.

[2] Z. Zheng ping, Y. Chu ming, and C. Yan feng, "Discussion about the Inter-laminar Insulation Fault Detection Method of the Large Generator Stator Core," Large Electric Machine and Hydraulic Turbine, vol. 9, 2009.

[3] S. Voßkühler, "Die Bedeutung von Diagnosemessungen für die Zustandsbewertung von Generator am Beispiel derVerlustfaktorund Hochinduktions Prüfung," in ETG-Kongress, Dusseldorf, 2009.

[4] M. Baca, P. Haschke, H. Twellmann, and C. Richter, "Blechpaketprüfanordnung," EP1601985, 2008.

[5] H. R. Tomlinson, "Interlaminar Insulation Test ror Synchronous Machine Stators," Transactions of the American Institute of Electrical Engineers. Part III: Power Apparatus and Systems, vol. 71, no. 3, p. 2, 1952.

[6] P. S. Hamer, "Acceptance testing of electric motors and generators," IEEE Transactions on Industry Applications, vol. 24, no. 6, 1988.

[7] D. B. Paley, "Current low power core testing using EL CID," in IEE Colloquium Understanding Your Condition Monitoring, Chester, UK, 1999, vol. 1999, pp. 7-7.

[8] P. 0' Donnell, "Report of Large Motor Reliability Survey of Industrial and Commercial Installations, Part I," IEEE Transactions on Industry Applications, vol. IA21, no. 4, pp. 853-864, 1985.

[9] J. Sutton, "EL Cid: an easier way to test stator cores," Electrical Review, vol. 207, pp. 33-37, 1980. 
RESISTOR (elektRonika kEndali telekomunikaSI tenaga liSTrik kOmputeR) Vol. 1 No. 2 e-ISSN : 2621-9700, p-ISSN : 2654-2684

[10] J. Sutton and B. F. Chapman, "Electromagnetic detection of damagedregions in laminated iron cores," in Proc. Int. Conf. Elect. Mach.Designand Applications, Hungary, 1982.

[11] J. W. Shelton and B. M. Reichman, "A Comparative Analysis of Turbo-Generator Inspection Techniques (East Pittsburgh, PA: Westinghouse Power Generator)," 1985.

[12] J. Sutton, M. Sasic, and D. R. Bertenshaw, "30 Years Experience with. EL CID Stator Core Testing," in Iris Rotating Machine Conf., Long Beach, 2008.

[13] D. R. Bertenshaw, "Analysis of stator core faults - a fresh look at the EL CID vector diagram," lnt. J. Hydropower Dams, 2006.

[14] J. Sutton, "Method and apparatus for testing laminated magnetic cores," 7930249, 1979.

[15] J. Sutton, "Electromagnetic core imperfections detector - an easy way to test stator cores," CEGB Res, pp. 15-21, 1982.

[16] C. Rickson, "Electrical machine core imperfection detection," IEE Proc.-Elect. Power Appl., vol. 33, no. 3, pp. 190-195, 1986.

[17] A. P. Chattock, On a Magnetic Potentiometer. Philosophical Magazine, 1887.

[18] C.-G. Richter and J. R. Weidner, "Testing stator cores of turbo generator using the ring flux method." Siemens, 2013. 